\title{
Penerapan Batas Ramp-Rate Menggunakan Kombinasi Metode FDP (Forward Dynamic Programming) dan QP (Quadratic Programming) Pada Unit Commitment- Economic Dispatch
}

\author{
Riza Fahmi Andriyanto, Ontoseno Penangsang, Ni Ketut Aryani \\ Jurusan Teknik Elektro, Fakultas Teknologi Industtri, Institut Teknologi Sepuluh Nopember (ITS) \\ Jl. Arief Rahman Hakim, Surabaya 60111 \\ e-mail: ontosenop@ee.its.ac.id, Ketut.Aryani@ee.its.ac.id
}

\begin{abstract}
Abstrak - Kebutuhan akan energi listrik terus menigkat seiring dengan perkembangan teknologi. meningkatnya beban listrik ini harus diimbangi dengan penambahan daya yang dibangkitkan. Hal ini sangat berpengaruh pada penjadwalan unit pembangkit yang harus ditentukan dengan baik agar didapatkan pembangkitan yang optimal. Pada Tugas Akhir ini mengambil topik mengenai unit commitment dan economic dispatch dengan mempertimbangkan nilai dari batasan generator (ramp-rate). Metode yang digunakan adalah complete enumeration dengan forward dynamic programming pada unit commitment dan quadratic programming pada economic dispatch. Metode - metode tersebut diterapkan dalam pemrograman matlab sehingga dapat dijadikan suatu program perhitungan unit commitment dan economic dispatch dengan mempertimbangkan nilai batasan ramp-rate.
\end{abstract}

Kata kunci-Unit Commitment, Economic Dispatch, Quadratic Programming.

\section{PENDAHULUAN}

$\mathrm{E}$ NERGI listrik adalah salah satu energi yang sangat dibutuhkan bagi kehidupan manusia. Permintaan energi listrik terus bertambah seiring bertambahnya jumlah penduduk. Permintaan daya listrik yang terus meningkat menyebabkan produksi daya listrik yang terus meningkat. Untuk mengimbangi permintaan ketersediaan energi listrik dibutuhkan kapasitas pembangkit listrik yang mengalami peningkatan terus menerus, sehingga dibutuhkan kombinasi nyala-mati unit pembangkit [1]. Jumlah beban yang harus disuplai unit-unit pembangkit selalu berubah setiap waktu. Oleh karena itu, pada penyaluran daya listrik, jumlah energi listrik terbangkitkan harus bernilai sama dengan jumlah beban yang harus disuplai untuk memperoleh biaya pembangkitan paling ekonomis. Selain itu penjadwalan unit pembangkit harus memperhatikan cadangan berputar. Jenis operasi sistem tenaga listrik area pembangkitan dapat berupa peningkatan dan penurunan daya output, serta penyalaan dan pemadaman unitunit pembangkit untuk mengimbangi jumlah beban yang ditanggung unit-unit pembangkit,

Unit commitment adalah penjadwalan nyala-mati unit-unit pembangkit yang beroperasi pada suatu sistem tenaga listrik.
Penyalaan dan pemadaman unit pembangkit pada suatu sistem tenaga listrik memiliki banyak pertimbangan, seperti ramprate, cadangan berputar (spinning reserve), waktu nyala minimal (minimum up time), waktu padam minimal (minimum down time).

Setiap unit pembangkit memiliki karakteristik input-output yang khas yang sangat mempengaruhi fungsi biaya pembangkitan unit pembangkit. Pada Tugas Akhir ini akan digunakan algoritma forward dynamic programming untuk menyelesaikan permasalahan unit commitment untuk mendapatkan kondisi yang optimal.

\section{TINJAUAN PUSTAKA}

\section{A. Unit Commitment}

Unit commitment $(U C)$ merupakan penjadwalan waktu penyalaan dan penghubungan unit pembangkit pada suatu sistem tenaga listrik yang direncanakan dalam waktu yang bervariasi dari beberapa jam hingga beberapa hari, dengan tujuan utama untuk memenuhi permintaan beban. Secara umum, penjadwalan UC ditentukan untuk beberapa hari ke depan. Permintaan beban per jam untuk permasalahan UC merupakan hasil peramalan beban yang tepat. Kriteria optimisasi untuk menentukan penjadwalan UC adalah biaya pembangkitan yang perlu diminimalkan selama periode perencanaan namun tetap memenuhi semua kendala sistem yang timbul dari batas kemampuan fisik unit pembangkit. Sebuah unit pembangkit memiliki berbagai batasan seperti ramp-rate, minimum up-down time, batas generasi maksimum dan minimum [2].

Pada penjadwalan unit commitment terdapat banyak faktor yang perlu diperhitungkan, yaitu:

1. Batasan dan biaya operasi tiap unit pembangkit

2. Batasan ramp-rate

3. Batasan dan biaya penyalaan dan pemadaman

Secara teoritis, fungsi objektif dari unit commitment adalah jumlah seluruh biaya bahan bakar, termasuk biaya penyalaan dan pemadaman dari unit-unit pembangkit yang menyuplai beban pada rentang waktu tertentu [2].

$F_{H}=\sum_{h=1}^{H} \sum_{n=1}^{N}\left[F_{n h}\left(P_{n h}\right)+S T C_{n h}\left(1-U_{n(h-1)}\right)\right] U_{n h}+D C_{n h}\left(U_{n}(h-1)^{-0}\right)(1)$ 
Untuk $F_{n h}\left(P_{n h}\right)$ dirumuskan

$$
F_{n h}\left(P_{n h}\right)=a_{n}\left(P_{n h}\right)^{2}+b_{n}\left(P_{n h}\right)+C_{n}
$$

Untuk $S T C_{n h}$ dirumuskan

$$
\begin{gathered}
H S C_{n} \quad \text { jika } M D T_{n} \leq T_{n}^{\text {off }} \leq M D T_{n}+C S H_{n} \\
C S C_{n} \quad \text { jika } T_{n}^{\text {off }}>M D T_{n}+C S H_{n}
\end{gathered}
$$

Untuk batasan-batasan lain adalah:

Ramp-Rate

$$
\begin{aligned}
& P_{n}(h-1)-P_{n}(h) \leq D R_{n} \\
& P_{n}(h-1)-P_{n}(h) \leq D R_{n}
\end{aligned}
$$

Rentang daya pembangkitan

$$
U_{n h} P_{n(\max )} \geq P_{n h} \geq U_{n h} P_{n(\min )}
$$

Waktu nyala minimal

$$
T_{n}^{o n} \geq M U T_{n}
$$

Waktu padam minimal

$$
T_{n}^{o f f} \geq M D T_{n}
$$

Cadangan Berputar

$$
\sum_{i=1}^{N}\left(P_{n(\max )}-P_{n h}\right) \geq R_{h}
$$

Keterangan:

$F_{H} \quad=$ biaya total pembangkitan pada $\mathrm{H}$ jam

$N \quad=$ jumlah unit pembangkit yang tersedia

$H \quad=$ jumlah periode jam penjadwalan

$n \quad=$ indeks unit $(n=1,2, \ldots ., \mathrm{N})$

$h \quad=$ indeks jam $(h=1,2, \ldots \ldots, \mathrm{H})$

$F_{n h}\left(P_{n h}\right)=$ fungsi biaya bahan bakar unit $\mathrm{n}$ pada jam $h$

$S T C_{n h} \quad=$ biaya penyalaan unit $n$ pada jam $h$

$H S C_{n} \quad=$ biaya penyalaan panas unit $n$ pada jam $h$

$\operatorname{CSC}_{n} \quad=$ biaya penyalaan dingin unit $n$ pada jam $h$

$U_{n h} \quad=$ variabel kontrol status nyala/mati unit pembangkit $n$ pada jam $h$

$D C_{n h} \quad=$ biaya pemadaman unit $n$ pada jam $h$

$a_{n}, b_{n}, C_{n}=$ koefisien fungsi biaya unit $n$

$P_{n h} \quad=$ daya terbangkit unit pembangkit $n$ pada jam $h$

$P_{n h(\max )}=$ daya output maksimal untuk unit pembangkit $n$ pada jam $h$

$D R_{n} \quad=$ Batas bawah ramp-rate

$U R_{n} \quad=$ Batas atas ramp-rate

$R_{h} \quad=$ cadangan berputar pada jam $h$

$T_{\text {on }} / T_{\text {off }}=$ rentang waktu selama unit $\mathrm{n}$ menyala atau padam

$M U T_{n} \quad=$ waktu nyala minimal unit $n$

$M D T_{n} \quad=$ waktu padam minimal unit $n$

$P_{n(\max )} / P_{n(\min )}=$ daya output maksimal $/$ minimal unit $n$

\section{METODE PENELITIAN}

\section{A. Economic Dispatch dengan Quadratic Programming}

Economic Dispatch adalah suatu metode perhitungan baya produksi tiap jamnya. Pada tugas akhir ini, karakteristik inputoutput dari pembangkit yang dipakai non-linier dengan orde dua. Dengan fungsi kuadrat pada karakteristik input-output yang ada. Quadratic programming bekerja setelah data-data seperti besarnya daya yang dapat dibangkitkan pembangkit dan incremental cost telah didapat. Besarnya daya setiap generator dimasukkan sebagai input pada economic dispatch bersama karakteristik input-output, kemudian quadratic programming sebagai metode akan mengolah daya dan karakteristik menjadi bentuk biaya.

Quadratic programming memiliki dimensi penyelesaian masalah sebanyak jumlah pembangkit yang ada, tidak melihat apakah pembangkit tersebut dalam keadaan mati atau hidup. Ini mengakibatkan quadratic programming dapat mengambil suatu keputusanyang tidak feasible untuk dijalankan.

Quadratic programming akan mencari pembangkitan dengan total biaya paling optimal yang memenuhi permintaan daya listrik.

\section{B. Forward Dynamic Programming untuk penyelesaian Unit} commitment

Algoritma dynamic programming dapat dibuat bekerja secara mundur.Memulai analisa dari jam terakhir lalu kembali ke jam awal. Ini dilakukan untuk mempelajari dan menganalisa ulang jalur yang telah diambil untuk menuju jam terakhir dari jam awal. Sebaliknya, algoritma dynamic programming dapat dibuat bekerja maju, memulai dari jam awal ke jam terakhir. Pendekatan forward dynamic programming memiliki kelebihan dalam penyelesaian unit commitment. Keuntungan penggunaan forward dynamic programming yaitu kondisi awal dapat dengan mudahdi tentukan pada perhitungan dapat terus berlanjut selama diperlukan [3].

Fungsi dari forward dynamic programming untuk menghitung biaya nimimum dalam jam $\mathrm{K}$ dengan kombinasi I adalah:

$$
\mathrm{F}_{\text {cost }}(\mathrm{K}, \mathrm{I})=\mathrm{MIN}\left[\mathrm{P}_{\text {cost }}(\mathrm{K}, \mathrm{I})+\mathrm{S}_{\text {cost }}(\mathrm{K}-1, \mathrm{~L}, \mathrm{~K}, \mathrm{I})\{\mathrm{L}\}+\mathrm{F}_{\text {cost }}(\mathrm{K}-1, \mathrm{~L})\right]
$$

State (K,I) merupakan kombinasi ke -I pada jam ke K. Metode yang dipakai dalam penentuan kombinasi adalah complete enumeration, dimana semua kombinasi pembangkit diperhitungkan sebanyak $2^{\mathrm{n}}-1$.

Pada forward dynamic programming yang dimaksud stategy adalah transisi, atau path (jalur), dari satu state pada jam tertentu pada state selanjutnya pada jam selanjutnya.

\section{Proses Kerja Program}

Secara keseluruhan, program ini memiliki flowchart proses sebagai berikut: 


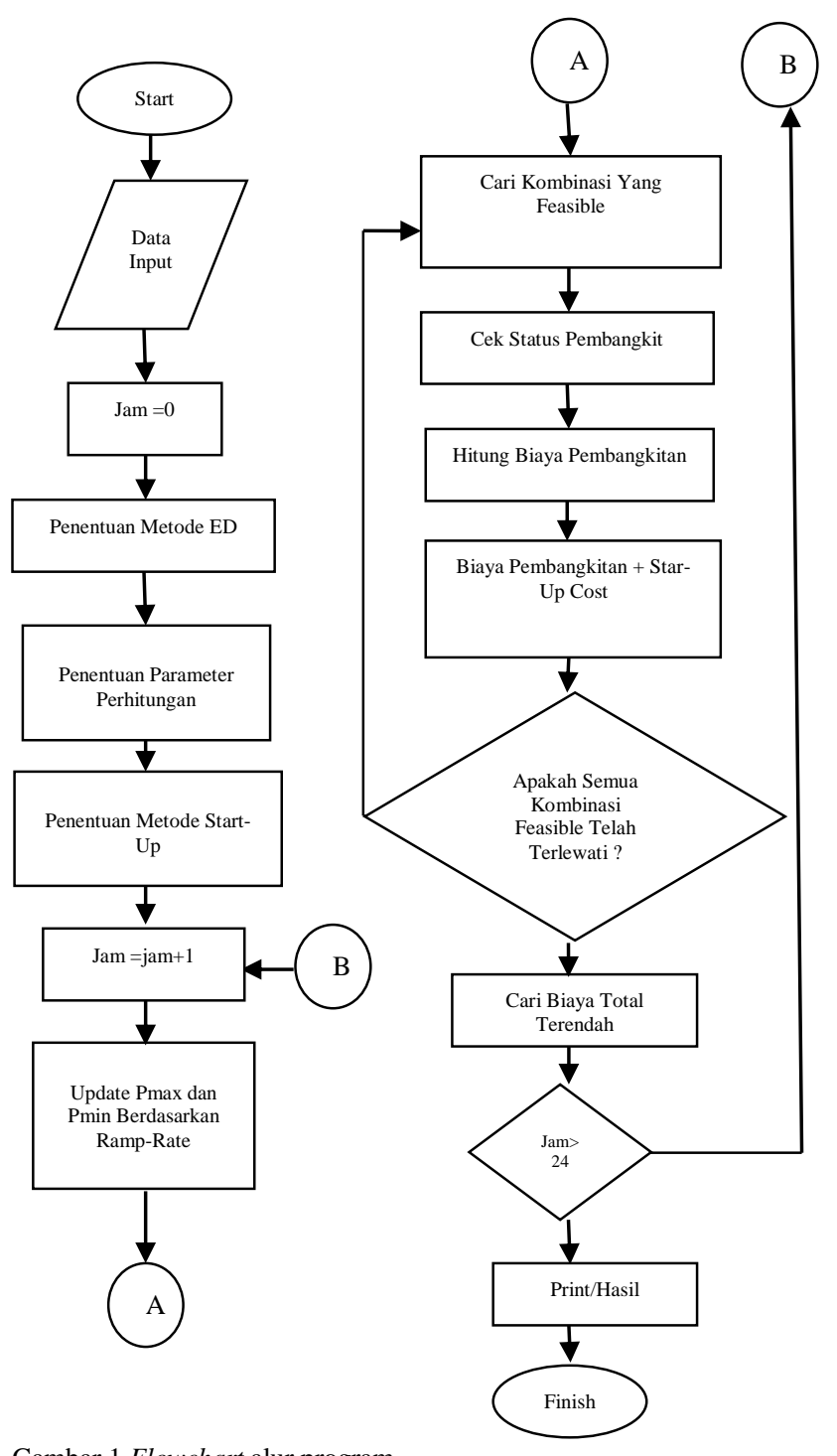

Gambar 1 Flowchart alur program

Dari alur program pada Gambar 1, dimana akan didapatkan nilai pembebanan pembangkit yang optimal dengan biaya pembangkitan termurah.

\section{HASIL DAN ANALISIS}

Pada Tugas Akhir ini terdapat 3 kasus yaitu:

\section{A. Studi Kasus 1}

Data-data pembangkit yang dipakai pada simulasi studi kasus 1, ditunjukkan pada tabel 1:

Tabel 1.

Data batasan unit pembangkit studi kasus 1

\begin{tabular}{cccccccc}
\hline \hline Unit & $\begin{array}{c}\text { Pmax } \\
(\mathrm{MW})\end{array}$ & $\begin{array}{c}\text { Pmin } \\
(\mathrm{MW})\end{array}$ & $\begin{array}{c}\text { Nyala } \\
\text { min } \\
\text { (jam) }\end{array}$ & $\begin{array}{c}\text { Padam } \\
\text { min } \\
\text { (jam) }\end{array}$ & UR & DR & Int \\
\hline 1 & 455 & 150 & 8 & 8 & 100 & 120 & 8 \\
2 & 455 & 150 & 8 & 8 & 100 & 120 & 8 \\
3 & 130 & 20 & 5 & 5 & 130 & 130 & -5 \\
4 & 130 & 20 & 5 & 5 & 130 & 130 & -5 \\
5 & 162 & 25 & 6 & 6 & 162 & 162 & -6 \\
6 & 80 & 20 & 3 & 3 & 80 & 80 & -3 \\
7 & 85 & 25 & 3 & 3 & 85 & 85 & -3
\end{tabular}

\begin{tabular}{cccccccc}
8 & 55 & 10 & 1 & 1 & 55 & 55 & -1 \\
9 & 55 & 10 & 1 & 1 & 55 & 55 & -1 \\
10 & 55 & 10 & 1 & 1 & 55 & 55 & -1 \\
\hline \hline
\end{tabular}

Tabel 2.

Data biaya operasi sistem studi kasus 1

\begin{tabular}{clcrrrr}
\hline \multirow{2}{*}{ Unit } & \multicolumn{3}{c}{ Koefisien biaya operasi } & \multicolumn{2}{c}{$\begin{array}{c}\text { Biaya penyalaan } \\
(\$)\end{array}$} & $\begin{array}{c}\text { Biaya } \\
\text { padam }\end{array}$ \\
\cline { 2 - 5 } & \multicolumn{1}{c}{$\mathrm{a}$} & \multicolumn{1}{c}{$\mathrm{b}$} & \multicolumn{1}{c}{$\mathrm{c}$} & Panas & Dingin & $(\$)$ \\
\hline 1 & 0,00048 & 16,19 & 1000 & 4500 & 9000 & 0 \\
2 & 0,00031 & 17,26 & 970 & 5000 & 10000 & 0 \\
3 & 0,002 & 16,6 & 700 & 550 & 1100 & 0 \\
4 & 0,00211 & 16,5 & 680 & 560 & 1120 & 0 \\
5 & 0,00398 & 19,7 & 450 & 900 & 1800 & 0 \\
6 & 0,00712 & 22,26 & 370 & 170 & 340 & 0 \\
7 & 0,0079 & 27,74 & 480 & 260 & 520 & 0 \\
8 & 0,00413 & 25,92 & 660 & 30 & 60 & 0 \\
9 & 0,00222 & 27,27 & 665 & 30 & 60 & 0 \\
10 & 0,00173 & 27,29 & 670 & 30 & 60 & 0 \\
\hline \hline
\end{tabular}

Tabel 3.

Data pembebanan sistem pada studi kasus 1 dengan interval 24 jam

\begin{tabular}{cccc}
\hline \hline Jam ke & Beban (MW) & Jam ke & Beban (MW) \\
\hline 1 & 700 & 13 & 1400 \\
2 & 750 & 14 & 1300 \\
3 & 850 & 15 & 1200 \\
4 & 950 & 16 & 1050 \\
5 & 1000 & 17 & 1000 \\
6 & 1100 & 18 & 1100 \\
7 & 1150 & 19 & 1200 \\
8 & 1200 & 20 & 1250 \\
9 & 1300 & 21 & 1300 \\
10 & 1400 & 22 & 1100 \\
11 & 1450 & 23 & 900 \\
12 & 1500 & 24 & 800 \\
\hline \hline
\end{tabular}

Dari hasil simulasi program, didapatkan hasil biaya pembangkitan dan pembebanan pembangkit selama 24 jam.

Tabel 4.

Pembebanan pembangkit pada sistem studi kasus 1

\begin{tabular}{|c|c|c|c|c|c|c|c|c|c|c|}
\hline \multirow{2}{*}{$\begin{array}{c}\text { Jam } \\
\mathrm{Ke}\end{array}$} & \multicolumn{10}{|c|}{ Unit } \\
\hline & 1 & 2 & 3 & 4 & 5 & 6 & 7 & 8 & 9 & 10 \\
\hline 1 & 455 & 245 & 0 & 0 & 0 & 0 & 0 & 0 & 0 & 0 \\
\hline 2 & 455 & 295 & 0 & 0 & 0 & 0 & 0 & 0 & 0 & 0 \\
\hline 3 & 455 & 395 & 0 & 0 & 0 & 0 & 0 & 0 & 0 & 0 \\
\hline 4 & 455 & 455 & 0 & 0 & 40 & 0 & 0 & 0 & 0 & 0 \\
\hline 5 & 455 & 455 & 0 & 0 & 90 & 0 & 0 & 0 & 0 & 0 \\
\hline 6 & 455 & 455 & 0 & 130 & 60 & 0 & 0 & 0 & 0 & 0 \\
\hline 7 & 455 & 455 & 0 & 130 & 110 & 0 & 0 & 0 & 0 & 0 \\
\hline 8 & 455 & 455 & 0 & 130 & 160 & 0 & 0 & 0 & 0 & 0 \\
\hline 9 & 455 & 455 & 130 & 130 & 130 & 0 & 0 & 0 & 0 & 0 \\
\hline 10 & 455 & 455 & 130 & 130 & 162 & 68 & 0 & 0 & 0 & 0 \\
\hline 11 & 455 & 455 & 130 & 130 & 162 & 80 & 0 & 38 & 0 & 0 \\
\hline 12 & 455 & 455 & 130 & 130 & 162 & 80 & 0 & 55 & 33 & 0 \\
\hline 13 & 455 & 455 & 130 & 130 & 162 & 68 & 0 & 0 & 0 & 0 \\
\hline 14 & 455 & 455 & 130 & 130 & 130 & 0 & 0 & 0 & 0 & 0 \\
\hline 15 & 455 & 455 & 0 & 130 & 160 & 0 & 0 & 0 & 0 & 0 \\
\hline 16 & 455 & 440 & 0 & 130 & 25 & 0 & 0 & 0 & 0 & 0 \\
\hline 17 & 455 & 390 & 0 & 130 & 25 & 0 & 0 & 0 & 0 & 0 \\
\hline
\end{tabular}




\begin{tabular}{ccccccccccc}
18 & 455 & 455 & 0 & 130 & 60 & 0 & 0 & 0 & 0 & 0 \\
19 & 455 & 455 & 0 & 130 & 160 & 0 & 0 & 0 & 0 & 0 \\
20 & 455 & 455 & 130 & 130 & 162 & 68 & 0 & 0 & 0 & 0 \\
21 & 455 & 455 & 130 & 130 & 110 & 20 & 0 & 0 & 0 & 0 \\
22 & 455 & 455 & 130 & 0 & 0 & 60 & 0 & 0 & 0 & 0 \\
23 & 455 & 335 & 110 & 0 & 0 & 0 & 0 & 0 & 0 & 0 \\
24 & 455 & 215 & 130 & 0 & 0 & 0 & 0 & 0 & 0 & 0 \\
\hline \hline
\end{tabular}

Pada Tabel 4 menunjukkan hasil simulasi dengan menggunakan nilai batasan ramp-rate. Dapat dilihat semua daya pembangkitan untuk setiap unit tidak ada yang melanggar batasan ramp-rate.

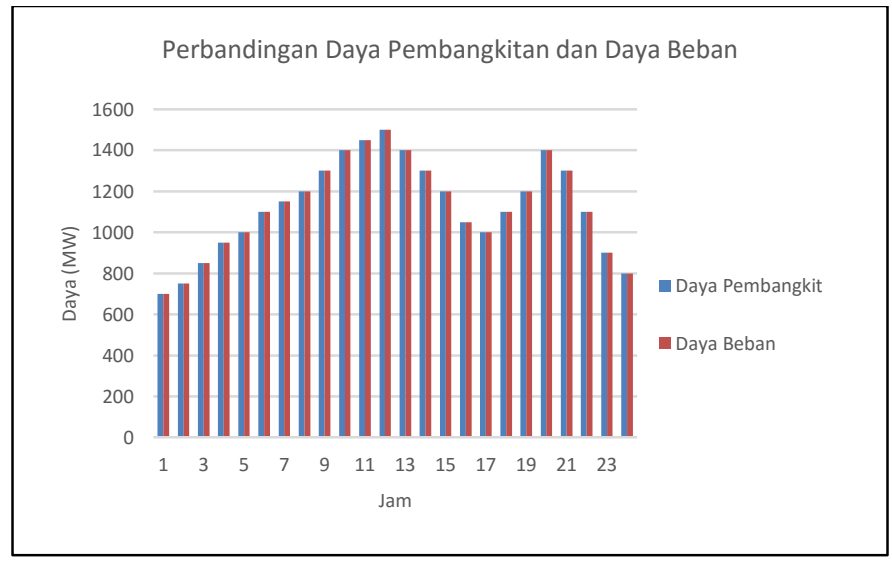

Gambar 2. Perbandingan daya pembangkitan dengandaya beban studi kasus 1

Total biaya pembebanan pada studi kasus 1 sebesar $546520.9 \$$

\section{B. Studi Kasus 2}

Data-data pembangkit yang dipakai pada simulasi studi kasus 2, ditunjukkan pada tabel 5:

Tabel 5.

\begin{tabular}{ccccc}
\multicolumn{5}{c}{ Tabel 5. } \\
\hline Data batasan unit pembangkit studi kasus 2 \\
\hline Unit & $\begin{array}{c}\text { Pmax } \\
(\text { MW })\end{array}$ & $\begin{array}{c}\text { Pmin } \\
(\text { MW })\end{array}$ & UR & DR \\
\hline 1 & 73 & 12 & 10 & 10 \\
2 & 93 & 26 & 15 & 15 \\
3 & 143 & 42 & 23 & 23 \\
4 & 70 & 18 & 10 & 10 \\
5 & 93 & 30 & 13 & 13 \\
6 & 350 & 100 & 50 & 50 \\
7 & 248 & 100 & 48 & 48 \\
8 & 190 & 40 & 20 & 20 \\
9 & 190 & 70 & 30 & 30 \\
10 & 113 & 40 & 20 & 20 \\
\hline \hline
\end{tabular}

Tabel 6.

Data biaya operasi sistem studi kasus 2

\begin{tabular}{cccc}
\hline \hline \multirow{2}{*}{ Unit } & \multicolumn{3}{c}{ Koefisien biaya operasi } \\
\cline { 2 - 4 } & $\mathrm{a}$ & $\mathrm{b}$ & $\mathrm{c}$ \\
\hline 1 & 0,0051 & 2,2034 & 15 \\
2 & 0,0040 & 1,9101 & 25 \\
3 & 0,0039 & 1,8518 & 40 \\
4 & 0,0038 & 1,6966 & 32 \\
5 & 0,0021 & 1,8015 & 29
\end{tabular}

\begin{tabular}{cccr}
6 & 0,0026 & 1,5354 & 72 \\
7 & 0,0029 & 1,2643 & 49 \\
8 & 0,0015 & 1,2130 & 82 \\
9 & 0,0013 & 1,1954 & 105 \\
10 & 0,0014 & 1,1285 & 100 \\
\hline \hline
\end{tabular}

Tabel 7.

Data pembebanan sistem studi kasus 2 selama 24 jam

\begin{tabular}{cccc}
\hline \hline Jam ke & Beban (MW) & Jam ke & Beban (MW) \\
\hline 1 & 480 & 13 & 1220 \\
2 & 710 & 14 & 1080 \\
3 & 930 & 15 & 850 \\
4 & 1000 & 16 & 800 \\
5 & 1200 & 17 & 1000 \\
6 & 1250 & 18 & 1200 \\
7 & 1400 & 19 & 1340 \\
8 & 1500 & 20 & 1400 \\
9 & 1340 & 21 & 1300 \\
10 & 1250 & 22 & 1100 \\
11 & 1400 & 23 & 900 \\
12 & 1300 & 24 & 680 \\
\hline \hline
\end{tabular}

Dari hasil simulasi program, didapatkan hasil biaya pembangkitan dan pembebanan pembangkit selama 24 jam.

Tabel 8.

Pembebanan pembangkit pada sistem studi kasus 2

\begin{tabular}{|c|c|c|c|c|c|c|c|c|c|c|}
\hline \multirow{2}{*}{$\begin{array}{c}\text { Jam } \\
\mathrm{Ke}\end{array}$} & \multicolumn{10}{|c|}{ Unit } \\
\hline & 1 & 2 & 3 & 4 & 5 & 6 & 7 & 8 & 9 & 10 \\
\hline 1 & 55 & 0 & 0 & 0 & 0 & 235 & 0 & 190 & 0 & 0 \\
\hline 2 & 65 & 0 & 0 & 0 & 0 & 285 & 100 & 190 & 70 & 0 \\
\hline 3 & 73 & 26 & 42 & 18 & 30 & 303 & 148 & 190 & 100 & 0 \\
\hline 4 & 63 & 41 & 64 & 28 & 43 & 253 & 188 & 190 & 130 & 0 \\
\hline 5 & 70 & 56 & 87 & 38 & 56 & 267 & 236 & 190 & 160 & 40 \\
\hline 6 & 66 & 71 & 110 & 48 & 69 & 258 & 248 & 190 & 190 & 0 \\
\hline 7 & 73 & 86 & 133 & 58 & 82 & 300 & 248 & 190 & 190 & 40 \\
\hline 8 & 73 & 93 & 143 & 68 & 93 & 342 & 248 & 190 & 190 & 60 \\
\hline 9 & 63 & 0 & 120 & 70 & 93 & 292 & 242 & 190 & 190 & 80 \\
\hline 10 & 53 & 26 & 97 & 65 & 93 & 242 & 194 & 190 & 190 & 100 \\
\hline 11 & 63 & 41 & 120 & 70 & 93 & 278 & 242 & 190 & 190 & 113 \\
\hline 12 & 0 & 56 & 112 & 70 & 93 & 228 & 248 & 190 & 190 & 113 \\
\hline 13 & 0 & 71 & 0 & 70 & 93 & 245 & 248 & 190 & 190 & 113 \\
\hline 14 & 0 & 0 & 0 & 70 & 93 & 199 & 225 & 190 & 190 & 113 \\
\hline 15 & 0 & 0 & 42 & 0 & 93 & 222 & 0 & 190 & 190 & 113 \\
\hline 16 & 0 & 26 & 65 & 0 & 93 & 236 & 0 & 190 & 190 & 0 \\
\hline 17 & 12 & 41 & 88 & 0 & 93 & 286 & 100 & 190 & 190 & 0 \\
\hline 18 & 22 & 56 & 111 & 18 & 93 & 332 & 148 & 190 & 190 & 40 \\
\hline 19 & 32 & 71 & 134 & 28 & 93 & 346 & 196 & 190 & 190 & 60 \\
\hline 20 & 42 & 86 & 141 & 38 & 93 & 296 & 244 & 190 & 190 & 80 \\
\hline 21 & 0 & 86 & 118 & 48 & 93 & 246 & 229 & 190 & 190 & 100 \\
\hline 22 & 0 & 71 & 0 & 58 & 93 & 196 & 189 & 190 & 190 & 113 \\
\hline 23 & 0 & 0 & 0 & 0 & 93 & 146 & 168 & 190 & 190 & 113 \\
\hline 24 & 0 & 0 & 0 & 0 & 0 & 0 & 187 & 190 & 190 & 113 \\
\hline
\end{tabular}

Tabel 8 menunjukkan hasil simulasi dengan menggunakan nilai batasan ramp-rate. Dapat dilihat semua daya pembangkitan untuk setiap unit tidak ada yang melanggar batasan ramp-rate. 


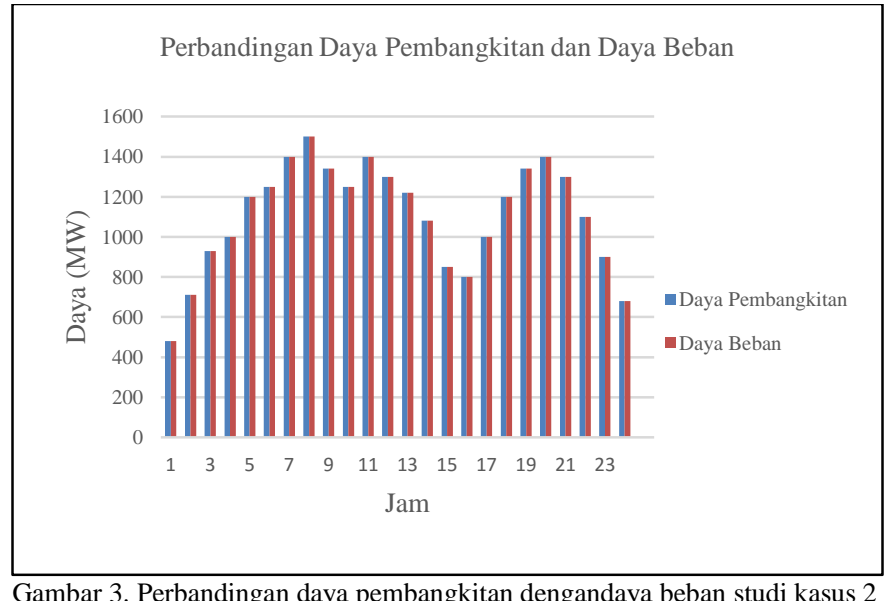

$\$$.

Total biaya pembebanan pada studi kasus 2 sebesar 60771.37

\section{Studi Kasus 3}

Data-data pembangkit yang dipakai pada simulasi studi kasus 3, ditunjukkan pada tabel 9:

Tabel 9.

Data batasan unit pembangkit studi kasus 3

\begin{tabular}{cccccccc}
\hline \hline Unit & $\begin{array}{c}\text { Pmax } \\
\text { (MW) }\end{array}$ & $\begin{array}{c}\text { Pmin } \\
(\text { MW })\end{array}$ & $\begin{array}{c}\text { Nyala } \\
\text { min } \\
(\text { jam })\end{array}$ & $\begin{array}{c}\text { Padam } \\
\text { min } \\
(\text { jam })\end{array}$ & UR & DR & Int \\
\hline 1 & 455 & 150 & 8 & 8 & 100 & 120 & 8 \\
2 & 455 & 150 & 8 & 8 & 100 & 120 & 8 \\
3 & 130 & 20 & 5 & 5 & 130 & 130 & -5 \\
4 & 130 & 20 & 5 & 5 & 130 & 130 & -5 \\
5 & 162 & 25 & 6 & 6 & 162 & 162 & -6 \\
6 & 80 & 20 & 3 & 3 & 80 & 80 & -3 \\
7 & 85 & 25 & 3 & 3 & 85 & 85 & -3 \\
8 & 55 & 10 & 1 & 1 & 55 & 55 & -1 \\
9 & 55 & 10 & 1 & 1 & 55 & 55 & -1 \\
10 & 55 & 10 & 1 & 1 & 55 & 55 & -1 \\
\hline \hline
\end{tabular}

Nilai dari cadangan berputar diambil $10 \%$ dari beban yang ditanggung setiap jamnya.

Tabel 10 .

Data biaya operasi sistem studi kasus 3

\begin{tabular}{clcrrrr}
\multicolumn{7}{c}{ Data biaya operasi sistem studi kasus 3 } \\
\hline \hline \multirow{2}{*}{ Unit } & \multicolumn{1}{c}{ Koefisien biaya operasi } & \multicolumn{2}{c}{ Biaya penyalaan } & \multirow{2}{*}{$\begin{array}{c}\text { Biaya } \\
\text { padam }\end{array}$} \\
\cline { 2 - 5 } & \multicolumn{1}{c}{$\mathrm{A}$} & $\mathrm{b}$ & $\mathrm{c}$ & Panas & Dingin & $(\$)$ \\
\hline 1 & 0,00048 & 16,19 & 1000 & 4500 & 9000 & 0 \\
2 & 0,00031 & 17,26 & 970 & 5000 & 10000 & 0 \\
3 & 0,002 & 16,6 & 700 & 550 & 1100 & 0 \\
4 & 0,00211 & 16,5 & 680 & 560 & 1120 & 0 \\
5 & 0,00398 & 19,7 & 450 & 900 & 1800 & 0 \\
6 & 0,00712 & 22,26 & 370 & 170 & 340 & 0 \\
7 & 0,0079 & 27,74 & 480 & 260 & 520 & 0 \\
8 & 0,00413 & 25,92 & 660 & 30 & 60 & 0 \\
9 & 0,00222 & 27,27 & 665 & 30 & 60 & 0 \\
10 & 0,00173 & 27,29 & 670 & 30 & 60 & 0 \\
\hline \hline
\end{tabular}

Tabel 11.

Data pembebanan sistem IEEE 39 bus 24 jam

\begin{tabular}{cccc}
\hline \hline Jam ke & Beban (MW) & Jam ke & Beban (MW) \\
\hline 1 & 700 & 13 & 1400
\end{tabular}

\begin{tabular}{cccc}
2 & 750 & 14 & 1300 \\
3 & 850 & 15 & 1200 \\
4 & 950 & 16 & 1050 \\
5 & 1000 & 17 & 1000 \\
6 & 1100 & 18 & 1100 \\
7 & 1150 & 19 & 1200 \\
8 & 1200 & 20 & 1250 \\
9 & 1300 & 21 & 1300 \\
10 & 1400 & 22 & 1100 \\
11 & 1450 & 23 & 900 \\
12 & 1500 & 24 & 800 \\
\hline \hline
\end{tabular}

Dari hasil simulasi program, didapatkan hasil biaya pembangkitan dan pembebanan pembangkit selama 24 jam.

Tabel 12.

Pembebanan pembangkit pada sistem studi kasus 3

\begin{tabular}{|c|c|c|c|c|c|c|c|c|c|c|}
\hline \multirow{2}{*}{$\begin{array}{c}\text { Jam } \\
\text { Ke }\end{array}$} & \multicolumn{10}{|c|}{ Unit } \\
\hline & 1 & 2 & 3 & 4 & 5 & 6 & 7 & 8 & 9 & 10 \\
\hline 1 & 455 & 245 & 0 & 0 & 0 & 0 & 0 & 0 & 0 & 0 \\
\hline 2 & 455 & 295 & 0 & 0 & 0 & 0 & 0 & 0 & 0 & 0 \\
\hline 3 & 455 & 370 & 0 & 0 & 25 & 0 & 0 & 0 & 0 & 0 \\
\hline 4 & 455 & 455 & 0 & 0 & 40 & 0 & 0 & 0 & 0 & 0 \\
\hline 5 & 455 & 390 & 0 & 130 & 25 & 0 & 0 & 0 & 0 & 0 \\
\hline 6 & 455 & 360 & 130 & 130 & 25 & 0 & 0 & 0 & 0 & 0 \\
\hline 7 & 455 & 410 & 130 & 130 & 25 & 0 & 0 & 0 & 0 & 0 \\
\hline 8 & 455 & 455 & 130 & 130 & 30 & 0 & 0 & 0 & 0 & 0 \\
\hline 9 & 455 & 455 & 130 & 130 & 85 & 20 & 25 & 0 & 0 & 0 \\
\hline 10 & 455 & 455 & 130 & 130 & 162 & 33 & 25 & 10 & 0 & 0 \\
\hline 11 & 455 & 455 & 130 & 130 & 162 & 73 & 25 & 10 & 10 & 0 \\
\hline 12 & 455 & 455 & 130 & 130 & 162 & 80 & 25 & 43 & 10 & 10 \\
\hline 13 & 455 & 455 & 130 & 130 & 162 & 33 & 25 & 10 & 0 & 0 \\
\hline 14 & 455 & 455 & 130 & 130 & 85 & 20 & 25 & 0 & 0 & 0 \\
\hline 15 & 455 & 455 & 130 & 130 & 30 & 0 & 0 & 0 & 0 & 0 \\
\hline 16 & 455 & 335 & 108 & 127 & 25 & 0 & 0 & 0 & 0 & 0 \\
\hline 17 & 455 & 260 & 130 & 130 & 25 & 0 & 0 & 0 & 0 & 0 \\
\hline 18 & 455 & 360 & 130 & 130 & 25 & 0 & 0 & 0 & 0 & 0 \\
\hline 19 & 455 & 455 & 130 & 130 & 30 & 0 & 0 & 0 & 0 & 0 \\
\hline 20 & 455 & 455 & 130 & 130 & 162 & 33 & 25 & 10 & 0 & 0 \\
\hline 21 & 455 & 455 & 130 & 130 & 85 & 20 & 25 & 0 & 0 & 0 \\
\hline 22 & 455 & 455 & 0 & 0 & 145 & 20 & 25 & 0 & 0 & 0 \\
\hline 23 & 455 & 425 & 0 & 0 & 0 & 20 & 0 & 0 & 0 & 0 \\
\hline 24 & 455 & 345 & 0 & 0 & 0 & 0 & 0 & 0 & 0 & 0 \\
\hline
\end{tabular}

Tabel 12 menunjukkan hasil simulasi dengan menggunakan nilai batasan ramp-rate dan batasan cadangan berputar. Dapat dilihat semua daya pembangkitan untuk setiap unit tidak ada yang melanggar batasan ramp-rate dan batasan spinning reserve. Total biaya pembebanan sebesar 559857 \$.

\section{KESIMPULAN}

Dari hasil simulasi dan analisis dapat diambil beberapa kesimpulan:

1. Pengaruh dari batasan ramp-rate pada daya pembangkitan yang sangat ketat, sehingga mencegah generator untuk 
bekerja secara maksimal dan memperpanjang live time dari unit.

2. Total biaya pembangkitan dengan mempertimbangkan nilai batasan ramp-rate lebih besar daripada tanpa batasan ramp-rate dikarenakan batasan ramp-rate akan menyebabkan variasi daya pembangkitan yang lebih ketat.

3. Metode quadratic programming dapat digunakan untuk melakukan perhitungan economic dispatch dengan menambahkan batasan ramp-rate dan spinning reserve.

4. Total biaya pembangkitan dengan mempertimbangkan cadangan berputar dengan batasan ramp-rate lebih mahal dibanding tanpa mempertimbangkan cadangan berputar dengan batasan ramp-rate, dikarenakan biaya tidak hanya dari daya pembangkitan saja tetapi juga diperhitungkan biaya pelepasan beban pada jam-jam yang melanggar batas spinning reserve.

\section{DAFTAR PUSTAKA}

[1] Saadat, Hadi, "Power System Analysis 2nd Edition", McGrowHill, Ch.1, 1999.

[2] Andrianto, Ryco, "Unit Commitment Pada Sistem IEEE 30 Bus Dengan 6 Pembangkit Termal Menggunakan Metode Binery Particle Swarm Optimazion ",Skripsi Jurusan Teknik Elektro FTIITS,Surabaya,2013

[3] C. Gana, "Unit Commitment Dengan Forward Dynamic Programming Mempertimbangkan Ramp-Rate dan Karakteristik Input-Output NonLinier Pada Setiap Pembangkit di Microgrid ",Skripsi Jurusan Teknik Elektro FTI-ITS,Surabaya,2012. 